\title{
NOTES
}

\section{"FATHER WALT": FRANCES WILLARD AND WALT WHITMAN}

In her 2000 essay, “'Don't let us talk of that anymore': Whitman's Estrangement from the Costelloe-Smith Family," Joann P. Krieg reconstructs the history of Whitman's mid-1880s complex, troubled, and mysterious friendship with the family of Hannah Whitall Smith, Robert Pearsall Smith, and their children, Mary, Logan, and Alys. Though Hannah and Robert never cared much for Whitman's poetry, Whitman enjoyed his visits to their home and greatly valued the attention and friendship of their precocious and wellconnected teenagers. After a few years of warm relationships with this family, Whitman was puzzled and hurt by their growing silence after they moved to England in $1888 .{ }^{1}$

Whitman first visited the Smiths' home in nearby Germantown from December 23-25, 1882; he records the visit in his Daybook: "Pleasant time at R. Pearsall Smith's and his wife Mrs Hannah W Smith ( $\&$ dear daughter Mary) ... the fine, long, spirited drives along the Wissahickon, the rocks and banks, the hemlocks, Indian Rock-Miss Willard, Miss Kate Sanborn, Lloyd Smith (R P's brother) the librarian." 2 The "Miss Willard" that Whitman names in this entry is Frances Willard, a feminist and temperance advocate, who was Hannah Whitall Smith's longtime friend. Willard's description of this visit, reprinted in a now-obscure 1979 Whitman Supplement and once mentioned in a Whitman reference guide, has never been taken up in Whitman scholarship despite its biographical and cultural significance. ${ }^{3}$

Incredibly, this visit was also documented by a third guest: further contextualizing this Whitman holiday is a 1915 account by the "Miss Kate Sanborn" mentioned in Whitman's daybook. This description has also been long known to Whitman scholars but never used in Whitman scholarship. ${ }^{4} \mathrm{~A}$ cousin of Franklin Benjamin Sanborn, the Transcendentalist scholar who had just published Henry D. Thoreau (1882), Kate Sanborn witnessed the meeting of Walt Whitman and Frances Willard and later recorded it as evidence of Willard's "gentle, forgiving, compassionate spirit" and "perfect self-control." Read in sequence, the two accounts contextualize the Smiths' invitation to Whitman and suggest that Willard had a complex and intriguing sympathy for Whitman as well as a desire to approve his character and poetry for her considerable audience of supporters.

First, here is Sanborn's recollection of the meeting, published a little more than thirty years later:

Visiting in Germantown, Pennsylvania, at the hospitable home of Mrs. Hannah Whitehall [sic] Smith, the Quaker Bible reader and lay evangelist, and writer of cheerful counsel, I found several celebrities among her other guests. Miss Willard and Walt 
Whitman happened to be present. Whitman was rude and aggressively combative in his attack on the advocate of temperance, and that without the slightest provocation. $\mathrm{He}$ declared that all this total abstinence was absolute rot and of no earthly use, and that he hated the sight of these women who went out of their way to be crusading temperance fanatics.

After this outburst he left the room. Miss Willard never alluded to his fiery criticism, didn't seem to know she had been hit, but chatted on as if nothing unpleasant had occurred.

In half an hour he returned; and with a smiling face made a manly apology, and asked to be forgiven for his too severe remarks. Miss Willard met him more than half-way, with generous cordiality, and they became good friends. And when with the women of the circle again she said: "Now wasn't that just grand in that dear old man? I like him the more for his outspoken honesty and his unwillingness to pain me."

How they laboured with "Walt" to induce him to leave out certain of his poems from the next edition! The wife went to her room to pray that he might yield, and the husband argued. But no use, it was all "art" every word, and not one line would he ever give up. The old poet was supposed to be poor and needy, and an enthusiastic daughter of Mrs. Smith had secured quite a sum at college to provide bed linen and blankets for him in the simple cottage at Camden. Whitman was a great, breezy, florid-faced out-of-doors genius, but we all wished he had been a little less au naturel. (Memories, 141-143)

It is impossible to know if the description is accurate or exaggerated, but this Whitman does sound like the man who later said, on May 2, 1888, that Franklin Evans was "damned rot." His attitudes toward temperance and temperance organizations changed over the years, and "rot" we know to be the verdict at the end of his life.

In recent years Willard, the president and organizing mastermind of the Woman's Christian Temperance Union (WCTU), has received more scholarly attention as an important figure, especially in the history of woman suffrage and women's oratory. ${ }^{7}$ It would be difficult to exaggerate the extent to which Willard was respected, if not revered, among well-educated Americans in the 1880s. Ostensibly she wrote her autobiography, Glimpses of Fifty Years (1889), in which Whitman makes a cameo appearance, as a fund-raiser for the WCTU, which published and promoted the work for a surging membership then nearing 150,000. It also ranked among the most culturally significant, critically acclaimed, and best-selling memoirs of the decade, so the fact that it generally approves of Whitman as a person and a poet may partially explain how he came to be accepted and embraced by the mainstream of the American literary audience. ${ }^{8}$

The autobiography is massive. At about 750 pages and more than 300,000 words, its bulk characterizes the tireless "Do Everything" policy of Willard's reform agenda. It is also literary. As a young woman Willard aspired to be a great writer, and she annotates her life with an extraordinary range of literary quotations, allusions, and book recommendations. She also recalls her own reading history as well as that of her notably well-educated family at every stage of their existence, which began, for Willard, in Oberlin, Ohio, and ended (after a period of gentlemanly farming in Wisconsin) in Evanston, Illinois. The 
autobiography surely functioned as a "college of one" for many of her readers. Even the most controlling and oppressive husband or father might not protest some quiet study of the widely accepted and carefully unobjectionable Frances Willard. It is also worth noting that Willard distinguished herself, prior to her involvement with the WCTU, as an English professor, the administrator of a pioneering women's college in Evanston, Illinois (later part of Northwestern University), and as one of the nation's foremost authorities on the education of women. Even had she not gone on to her career as the president of the WCTU, Willard would still be noted today as an important Western champion of higher education for women. For her 1889 audience, Willard would have had a commanding authority as a literary critic.

In the following extract, she describes Whitman as one of the interesting people that her reform career led her to meet and appreciate:

\section{WALT WHITMAN}

One Christmas I was in the home of Mrs. Hannah Whitall Smith, where I have met many most interesting literary people at her "hobby parties," which are a witty invention of her gifted husband, herself or her ingenious children, I do not know which, the plan being to have some person of distinction in a particular line of literary, moral or religious activity, as the central figure of the evening. Each of these persons brings out his or her hobby, and paces it up and down before the group, after which any other person has a right to ride upon it, if so disposed. This results in a really charming and informal conversation, following the brief special disquisition, and is the most enjoyable home entertainment I ever attended.

Finally the suggestion was made, "Why not ask Walt Whitman, who lives just across here in Camden? let us see him for ourselves;" and the invitation went. In due process of time, there appeared on the scene a man about seventy years of age, attired in gray, from his soft gray overcoat to his old-fashioned gray mittens, with sparse gray hair, kind, twinkling gray eyes, and russet apple cheeks, the mildest, most modest and simple-hearted man I ever saw. It almost seemed as if a grand old oak had opened suddenly and turned the good, gray poet loose upon the world. He is the farthest possible from being leonine in aspect or intent. He has no ends to serve, no place to hold in conversation, nothing to gain or lose. He is the soul of geniality and seems never better pleased than when others are talking and he is seated in a large arm-chair gazing reflectively into the glowing grate. But if you talk of nature and her shy ways, he is at home. I remember his look of amused surprise when someone mentioned the title of one of his books, "The Wake Robin," and he told us John Burroughs, who seems to me to be a sort of spiritual son to Whitman, had suggested it. ${ }^{9}$ I said, "I did not know what a Wake Robin was, unless it was a bird - they used to wake me early at Forest Home in olden days"-when, behold, the mild old man informed me gently that it was a flower! He did not like to talk about his books and seemed to me as a hunting hound lying at full length on the rug before the fire, content and quiet, until some reference is made to horses, hunting-horns and guns, when it rises up, intent, alert, electrified with activity. So the common hum and talk seemed quieting to Father Walt, but when Thoreau or Burroughs were referred to, or a quotation given from Wordsworth, Thomson, or some dear Nature-lover, the kindly eyes beamed upon us 
with joy, and some pithy sentence, clean-cut enough to be a proverb, fell from his lips. What he really is I do not know. I only tell about him as he was to me, and his sense of God, Nature and Human Brotherhood struck me as having been raised to such a power, and fused in such a white heat of devotion, that they made the man a genius. ${ }^{10}$

Willard smooths away the friction that Sanborn described as causing sparks at her meeting with Whitman. Sanborn's description of Whitman's "florid" cheeks is softened by Willard's sunny description of his "russet apple cheeks," and though Sanborn remembered Whitman behaving intemperately and "rude," Willard describes him as peaceful and in no way "leonine." She also places him, in her autobiography, in fairly illustrious company. The contemporary literary figure most associated with Willard was John Greenleaf Whittier, who wrote a preface for the 1886 second edition of her earlier book, Nineteen Beautiful Years (1864), a spiritual biography of her sister Mary. Other living writers featured near Whitman in Glimpses include Elizabeth Stuart Phelps (Ward), the Beecher family, Oliver Wendell Holmes, and a number of temperance authors such as Mary Lathbury and Sarah K. Bolton; some attention is also graciously paid, in the spirit of Reconstruction, to a series of Southern writers such as Joel Chandler Harris, Almira Lincoln Phelps, Sidney Lanier, and Paul Hamilton Hayne. Intermixed with accounts of these writers are sketches of other cultural and political figures such as William Ewart Gladstone, the prime minister; Frances Folsom Cleveland, the First Lady; and Captain Richard Henry Pratt, "the Indian civilizer." "Genius," the word she uses to describe Whitman, is also applied to Henry Ward Beecher, who had recently died. Her description of genius accords with Whitman's poetic persona: "Genius would rather go and tell its story to the whole world than to an individual. There is no stronger proof of its universality than this. Poets and heroes always take the human race into their confidence-and to the everlasting credit of the race let it be said, that confidence is not abused!" (Glimpses, 535).

Whitman's account of the Christmas visit focuses on the "fine, long, spirited drives along the Wissahickon the rocks and banks, the hemlocks, Indian Rock." Sanborn remembers Whitman and Willard as "good friends" after Whitman's apology. And though Willard describes Whitman to her readers in a friendly way, she does not present Whitman as an enduring friend. Her description of Whitman as a hunting dog shows some desire to maintain an arm's length from Whitman the man; "What he really is I do not know," she writes. A similar passage can be found in a nearby description of the Pundita Ramabai Saraswati, a high-caste Indian feminist who was renowned in the United States for her beauty, her conversion from Hinduism to Christianity, her veganism, and most of all for her support for temperance organizations. "She is delightful to have about," Willard writes, "content if she has books, pen and ink, and peace. She seems a sort of human-like gazelle; incarnate gentleness, combined with such celerity of apprehension, such swiftness of mental pace, adroitness of logic, and equipoise of intention as make her a delightful mental problem" (Glimpses, 557). These animal comparisons suggest an inability to fully identify with the "otherness" of Whitman and Ramabai. 
Still, Willard's description of Whitman, especially as "Father Walt," shows some thoughtful sympathy. Like Whitman, she draped herself in the character and authority of a parental figure without ever having had children herself. Elsewhere, the autobiography displays the anxiety Willard could feel when questioned about her decision never to marry and have children, as well as her ability to speak for all mothers when she, herself, was not a mother. ${ }^{11}$ Just as Whitman could be regarded as more an "Old Bachelor" than a "Father," so could the forty-something "Miss Willard" be considered more an "Old Maid" than a "Mother." Willard built her political arguments on the necessity for women to unite in mutual love; just as Whitman stood for "Human Brotherhood," so Willard stood for the union of motherly women. Willard scholars debate the meaning of her series of intense and apparently romantic friendships with other women: to some, Willard is most obviously a significant lesbian figure in nineteenth-century America, while others dismiss her sexuality as irrelevant or too undocumented for any meaningful debate. ${ }^{12}$ Either way, it is certain that love among women was as important to Willard's writings and political oratory as love among men was important to Whitman's poetry. And while Willard does not go so far as Sanborn suggests - she does not introduce Whitman to her WCTU membership as her "good friend"-it does seem that Whitman and Willard shared friendly feelings toward one another, and it is clear she made an effort to recommend Whitman to her readers in a warm and generous light. (Meanwhile Hannah was in the other room, praying that Whitman would leave out some of his more sinful poems from the next edition of Leaves of Grass.)

Finally, Willard's description of Whitman's place in the Smith home does not reflect so well on the Smiths. They appear to have regarded him as an amusing curiosity whose presence their wealth could command, on the spur of the moment, for the edification of their indulged and ingenious children. There have been several accounts of how Whitman was initially invited to the Smith home in 1882 (Krieg, 93), but Willard's recollection that it was the result of a kind of parlor game underscores the family's robust sense of entitlement and does much to explain the mystery of how and why they could casually "drop" Whitman a few years later. ${ }^{13}$

University of Akron

JON MiLLER

\section{NOTES}

1 Joann Krieg, “'Don't let us talk of that any more': Whitman's Estrangement from the Costelloe-Smith Family," Walt Whitman Quarterly Review 17 (Winter 2000), 91120, and especially 93, 95, 103, and 115 .

2 Walt Whitman, Daybooks and Notebooks, ed. William White, (New York: New York University Press, 1977), 2:308.

3 See William White, ed., Walt Whitman Supplement, 160th Anniversary, 1979. The Long-Islander (May 31, 1979), 23-27, and Scott Giantvalley, Walt Whitman, 1838-1939: A Reference Guide (Boston: Hall, 1981), 93-94. 
4 See Walter Harding, "A Glimpse of Walt Whitman," Walt Whitman Newsletter 3 (March 1957), 7, where the passage from Sanborn's autobiography is reprinted.

5 Sanborn's biography of Thoreau mentions Whitman only in brief remarks about Thoreau's pilgrimage to see him. See Franklin Benjamin Sanborn, Henry D. Thoreau (Boston: Houghton Mifflin, 1882), 186-187. Sanborn, however, later wrote an important memoir of his meetings with Whitman from 1860 through 1881; it was published in The Conservator 8 (May 1897), 37-40. Kate Sanborn, Memories and Anecdotes (New York: Putnam, 1915), 141. Hereafter, Memories.

6 Horace L. Traubel, With Walt Whitman in Camden (various publishers, 19061996), 1:93.

7 The standard biography of Willard remains Ruth Bordin, Frances Willard: A Biography (Chapel Hill: University of North Carolina Press, 1986). Also of note is Carolyn De Swarte Gifford, Writing Out My Heart: Selections from the Fournal of Frances E. Willard, 1855-96 (Urbana: University of Illinois Press, 1995), and her essay, "The Woman's Cause Is Man's," Gender and the Social Gospel, ed. Wendy J. Deichmann Edwards and Carolyn De Swarte Gifford (Urbana: University of Illinois Press, 2003), 21-34. Willard figures in Holly Berkley Fletcher, Gender and the American Temperance Movement (New York: Routledge, 2008), which argues that the "crusader" imagery of the WCTU was primarily a pragmatic means to build a political coalition. Alison M. Parker re-examines the WCTU's censorship agenda with surprising conclusions in Purifying America: Women, Cultural Reform, and Pro-Censorship Activism, 1873-1933 (Urbana: University of Illinois Press, 1997), and continues her work with Willard's political agenda in Articulating Rights: Nineteenth-Century American Women on Race, Reform, and the State (DeKalb: Northern Illinois Press, 2010). Nan Johnson, Gender and Rhetorical Space in American Life, 1866-1910 (Carbondale: Southern Illinois University Press, 2002), includes a comprehensive summary of the scholarship on woman's rhetoric, which often includes analysis of the speeches of Frances Willard. An earlier book-length study of her oratory is Richard W. Leeman, "Do Everything" Reform: The Oratory of Frances E. Willard (New York: Greenwood Press, 1992). The only significant mention of Willard in Whitman scholarship is in Sherry Ceniza, Walt Whitman and Nineteenth-Century Women Reformers (Tuscaloosa: University of Alabama Press, 1998), 216, where she is invoked as a contrast to the kinds of women reformers Whitman knew and liked.

8 For example, see these reviews: "Notes," The Critic: A Weekly Review of Literature and the Arts (January 29, 1887), 59-60; Amanda M. Wilson, "Frances E. Willard," Zion's Herald (October 9, 1889), 326; Untitled review of Glimpses of Fifty Years, by Frances E. Willard, Zion's Herald (December 11, 1889), 394; Lillian Whiting, "A Study of Miss Frances E. Willard's 'Glimpses of Fifty Years,'” Daily Inter Ocean (August 3, 1889), 10.

9 Wake-Robin is not a Whitman book, of course, but an 1871 work by John Burroughs. If this anecdote is accurate, Willard appears to have mistaken Wake-Robin for a work of Whitman's. Whitman, with "no place to hold in conversation, nothing to gain or lose," avoids giving offense by declining to correct her. His response to her compliment on the work's title - that it was the suggestion of John Burroughs-is therefore gently comic.

10 Frances E. Willard, Glimpses of Fifty Years: The Autobiography of An American Woman (Chicago: Woman's Temperance Publication Association, 1889), 541-542. Hereafter, Glimpses. 
11 For example, see Willard's comparison of herself to Susan B. Anthony (Glimpses, 598).

12 Ruth Bordin, for example, concludes that Willard's "primary emotional ties" were all with women but "they seem not have been explicitly homosexual"; see Bordin, "Willard, Frances Elizabeth Caroline," American National Biography (New York: Oxford University Press, 2002). Yet Willard figures in Lillian Faderman, To Believe in Women: What Lesbians Have Done for America (Boston: Houghton Mifflin, 1999). See also Jean H. Baker, Sisters: The Lives of America's Suffragists (New York: Hill and Wang, 2006).

13 For Bucke's letters to Whitman about his chilly reception at the Smiths' in London, see Richard Maurice Bucke, Medical Mystic: Letters of Dr. Bucke to Walt Whitman and His Friends, ed. Artem Lozynsky (Detroit: Wayne University Press, 1977), 154-164. Whitman's parenthetical question to Bucke-"(have they dropt me?)"-is in Walt Whitman, The Correspondence, ed. Edwin Haviland Miller (New York: New York University Press, 1961-1969), 5:223.

\section{LOS ANGELES, 1960: JOHN F. KENNEDY AND WHITMAN'S SHIP}

\section{OF DEMOCRACY}

Walt Whitman had a long and meaningful relationship with the United States presidency. With brothers named George Washington, Thomas Jefferson, and Andrew Jackson Whitman, the poet seemed destined to grow up positioning his work in relation to both the office and the men who occupied it. From the bitter rhetoric of "The Eighteenth Presidency!" to the astonishing art of "When Lilacs Last in the Dooryard Bloom'd," Whitman paralleled his poetic achievement with the nation's highest office. It was with a combination of respect, frustration, and rivalry that he wrote of Americans, in the preface to the 1855 edition of Leaves of Grass, "Their Presidents shall not be their common referee so much as their poets shall."

Presidents and presidential candidates have had their own history with Whitman. James Garfield and Grover Cleveland met Whitman and admired Leaves of Grass. ${ }^{1}$ Teddy Roosevelt described Whitman as a Dante of the Bowery and lamented that more Americans did not know his work. ${ }^{2}$ The five-time Socialist presidential candidate Eugene Debs had deep affection for Leaves of Grass and regularly corresponded with Horace Traubel and the Walt Whitman Fellowship. Modern presidents have been particularly fond of invoking "I Hear America Singing." Lyndon Johnson quoted from the poem when he introduced a jobs bill to Congress in $1967 .^{3}$ Ronald Reagan referred to the poem when speaking to the Conservative Political Action Committee about his 1984 landslide victory. ${ }^{4}$ Richard Nixon quoted from "Song of the Broad-Axe" in a speech about community development, and the elder George Bush adapted a line from "Starting from Paumanok" in a speech to religious broadcasters. ${ }^{5}$

A search of the American Presidency Project (an online archive hosted by the University of California, Santa Barbara) reveals that Bill Clinton quoted Whitman seven times during his presidency. As Ed Folsom has written, how- 